\title{
25
}

\section{Family Policy: Neglected Determinant of Vertical Income Inequality}

\author{
Rense Nieuwenhuis
}

Family policies have played a pivotal role in facilitating the rise of employment and earnings of women (Gornick \& Meyers, 2003; Nieuwenhuis, Need, \& Van der Kolk, 2012; Olivetti \& Petrongolo, 2017; Thévenon, 2011), one of the most prominent developments in economic activity in OECD countries in recent decades. As has been demonstrated in an exhaustive literature and throughout this Handbook, family policies of various kinds have featured prominently in analyses of the differences in the economic activity between groups, such as women and men or mothers and women without children. These are examples of horizontal income inequality: income differences between groups of individuals. At the same time, a concern for high and rising levels of income inequality between households (re)emerged, focusing on factors such as globalization, technological change, wealth accumulation, and austerity as explanations for rising income differences between households (Atkinson, 2015; Iversen \& Soskice, 2019; Milanovic, 2016; OECD, 2015; Piketty, 2014; Taylor-Gooby, Leruth, \& Chung, 2017). This is often referred to as vertical income inequality: inequality between individuals or households based on their place in the income distribution. In this literature on vertical income inequality, the potential role of family policies has been neglected. This is surprising, as horizontal and vertical income inequality are inherently linked: as family policies reduce the income differences between

R. Nieuwenhuis $(\otimes)$

Swedish Institute for Social Research (SOFI), Stockholm University, Stockholm, Sweden

e-mail: Rense.nieuwenhuis@sofi.su.se 
women and men-or other groups of individuals - this affects not only income differences within households, but also between. In this chapter I set the record straight and develop a research agenda that incorporates family policies as an institutional determinant of vertical income inequality between households.

First, I elaborate upon how analyses of vertical income inequality and horizontal income inequality have generally considered widely different types of determinants. In line with the scope of this Handbook, the emphasis will be on institutional determinants. I will then demonstrate that women's employment and earnings directly relate to levels of economic inequality among households; as levels of vertical and horizontal inequality are interrelated, so are their determinants. This, finally, brings into focus the perspective on how family policies might affect vertical income inequality between households, and what research questions this raises. This new perspective is, naturally, well-informed by the existing literature on the economic outcomes of family policies, of which key references are highlighted here. It also raises new questions, that are explored in conclusion.

\section{The Different Determinants of Horizontal and Vertical Income Inequality}

Contemporary analyses of income inequality emphasize how in most advanced capitalist societies (including most European and OECD countries) inequality has been rising since the 1980 s, although to varying degrees. Between the mid-1980s and 2013, vertical income inequality, as measured by the so-called Gini coefficient, increased on an average with over $10 \%$ in the OECD, with inequality rising fastest in Sweden with a 35\% increase (OECD, 2015). Gini coefficients measure the income differences among all households (accounting for the number of individuals living in these households). As such, this is a form of vertical income inequality, pertaining to the overall shape of the income distribution and thus analyzing how far all individuals or households in a given population are apart. This is depicted on the vertical axis in Fig. 25.1. Naturally, such analyses can focus on a variety of income concepts, including earnings and wages.

Prominent explanations have been formulated for rising levels of vertical income inequality. Examples of key determinants have been depicted in Fig. 25.1, and include the impact of globalization (on levels of inequality within countries) (Milanovic, 2016), European integration (Beckfield, 2019), robotization and algorithms, or more precisely skills-biased technological 


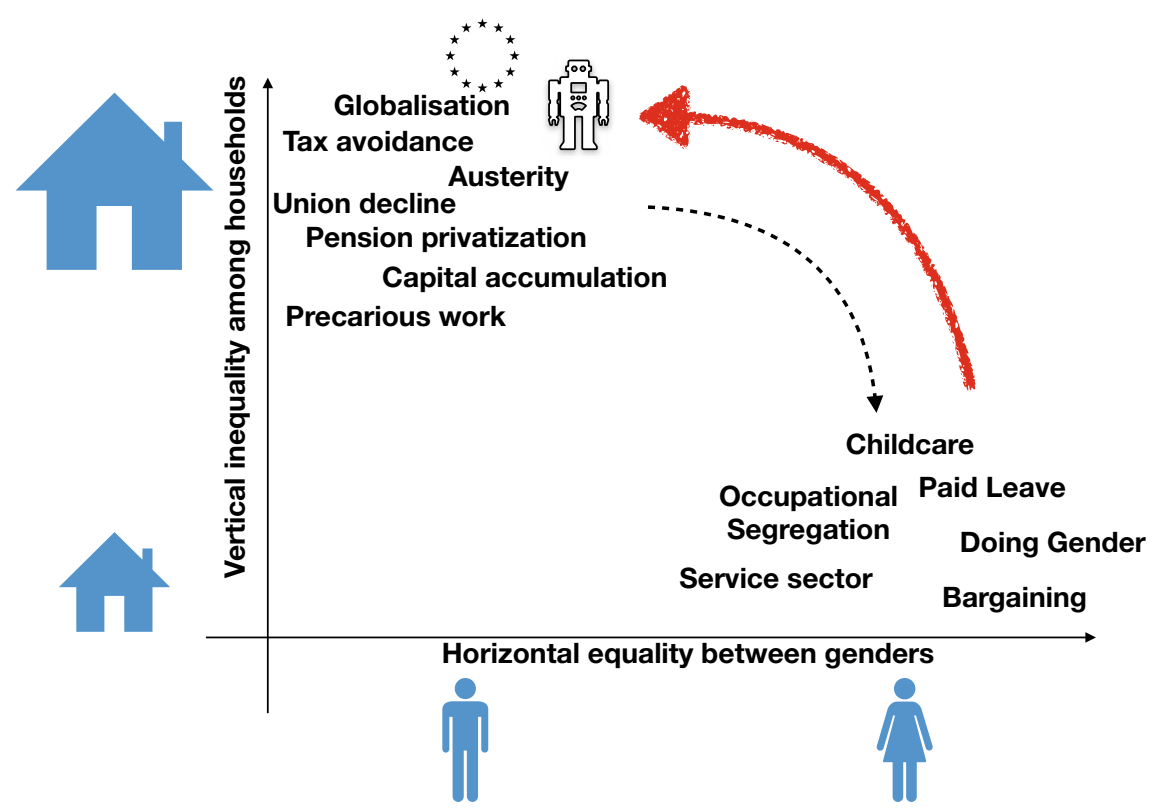

Fig. 25.1 Selected determinants of vertical and horizontal economic inequality

change (Atkinson, 2015; Autor, 2014; Frey, 2019), the accumulation of capital (Piketty, 2014), pension privatization (Ebbinghaus, 2011), polarization between high- and low-skilled workers in the transition to the knowledge economy (Iversen \& Soskice, 2019), precarious work and the return to mass unemployment (Bernstein, 2016; Kalleberg, 2009; Lohmann \& Marx, 2018), decline in unionization (Ebbinghaus \& Visser, 2000; Korpi, 1983), tax avoidance (Saez \& Zucman, 2019), austerity (Taylor-Gooby et al., 2017), and longer term processes of welfare state retrenchment-in particular with respect to social assistance and other aspects of minimum income protection (Marx \& Nelson, 2013; Nelson, 2013). Importantly, these developments are generally interrelated.

Income differences between women and men, a form of horizontal income inequality, have generally been declining in most countries over recent decades - although they have certainly not ceased to exist (Charles, 2011). Women have entered the labor market at much faster rates than men, closing the gender gap between women and men having an income of their own. Yet, while for instance in the EU 78\% of men were employed in 2017 (EU \& EIGE, 2020), only 66.5\% of women were. Among those who are employed, the gender pay gap has been closing slowly, but in the EU, in 2017 the gross hourly wage of women was only 84\% that of men (ibid.). Trends and levels of women's employment and gender inequality have been 
explained by a combination of demographic and institutional determinants (Nieuwenhuis et al., 2012). Demographic explanations of women's rising participation in the labor market (Lesthaeghe, 2010) include their rising educational levels (Bussemakers, Van Oosterhout, Kraaykamp, \& Spierings, 2017) and declining fertility (Van der Lippe \& Van Dijk, 2002). Institutional explanations, a selection of which are depicted on the horizontal axis of Fig. 25.1, pertain to determinants that include gender role norms in relation to "doing gender" (Evertsson, 2014; Knight \& Brinton, 2017; West \& Zimmerman, 2009), expansion of the service sector, horizontal and vertical occupational segregation (Charles \& Grusky, 2004), and overly long work hours expected in high-wage occupations (Goldin, 2014).

When it comes to family policies, it has often been observed - and demonstrated throughout this Handbook - that women's economic activity tends to be more equal to men's in welfare states based on dual-earner/caregiver policy models, characterized by public childcare for young children, brief periods of well-paid parental leave for both parents, as well as individual taxation, compared to in the traditional breadwinner model—characterized by very long periods of leave for mothers, childcare only for somewhat older children and joint taxation (Korpi, 2000; Lewis, 1992). With respect to specific policies, public childcare has been a key determinant for women's employment (Olivetti \& Petrongolo, 2017), as well as the motherhood wage penalty (Halldén, Levanon, \& Kricheli-Katz, 2016), in particular when it is available, affordable, and of adequate quality (Gambaro, Stewart, \& Waldfogel, 2015; also see Chapter 8 by Vandenbroeck in this volume). The provision of parental leave has also been instrumental to women's employment (Moss, Duvander, \& Koslowski, 2019), as long as it has been adequately paid (Gornick \& Meyers, 2003) and not overly long (Nieuwenhuis, Need, \& Van der Kolk, 2017a).

Although depicted as separate axes, there is a small literature showing that some of the determinants of vertical income inequality between households have also affected levels of horizontal income inequality between women and men. This is shown in Fig. 25.1 by the dashed, black arrow. For instance, Iversen and Soskice (2019) argue that the shift to the knowledge economy has been beneficial to the employment opportunities of in particular high-skilled women, whereas among the lower skilled women's jobs are considered at greater risk than men's of being replaced by automation (Brussevich et al., 2018). Albeit with huge differences across welfare states, austerity has rendered the social security on which women rely less effective, and has reduced wages and the number of jobs in the public sector in which women are overrepresented (Rubery, 2015). As women are more likely to have more 
restricted and incomplete contribution histories-in part related to a lack of formal family policy measures over the life course-women's old-age incomes might be hit harder than men's in relation to pension privatization (Möhring, 2015, 2016).

A clear gap in the literature is how family policies have affected levels and trends of vertical income inequality. It is of course true that some lines of research examine the link between family policies on overall levels of inequality. An example is literature studying whether particularly children growing up with socioeconomically disadvantages parents benefit from enrolment in early childhood education and care (ECEC), as such promoting overall levels of equality of opportunity (Gambaro et al., 2015, also see Chapter 8 by Vandenbroeck). Yet, this line of research does not explicitly address vertical income inequality, even though there are very good reasons and some initial evidence to suggest that family policies, indeed, can affect levels of inequality among households. This lacuna in the literature is the focus of this chapter, and is depicted in Fig. 25.1 by the long red arrow.

Developing a research agenda on the potential impact of family policies on levels and trends of vertical income inequality among households is important for at least three reasons. First and foremost, of substantive importance, it may demonstrate that the literature on income inequality needs to include an additional set of determinants, and the results may give policymakers an extra set of instruments to curb inequality. This does require, however, a detailed understanding of the mechanisms through which, and conditions under which, family policy instruments can attenuate levels of income inequality. Secondly, of methodological nature, the potential influence of family policies may be further underlined in relation to a gender perspective of how income inequality is typically measured. Many such analyses of income inequality are based on a measurement of household income, which is equivalized for the household size and composition to approximate levels of income inequality among individuals (Cowell, 2011). This assumes, however, that all household income is shared equally even though this is not the case (Bennett, 2013). As it is known that women who have an income of their own have more access to and control over household resources (Sen, 1990), family policies that facilitate women's employment and own incomes may reduce overall levels of vertical inequality in ways that are not captured by traditional measurements of inequality-including control over household resources. The alternative, measuring inequality solely based on individual incomes assumes no sharing of income and resources among household members, which seems equally unrealistic. As such, a focus on family policies that not only affect income differences between women and men in general, but also income differences 
within households, will provide a more comprehensive analysis of vertical income inequality as well. Finally, with respect to the academic community, it should be observed that researchers studying the determinants of economic inequality, and researchers studying family policy outcomes, tend to discuss their work at different conferences (or at the very least in different tracks of conferences) and tend to publish their work in different journals. This research agenda thus has the potential to bring these communities and literatures together, and foster a multidisciplinary cross-pollination.

\section{How Women's Earnings Affect Vertical Inequality}

Family policies can affect vertical income inequality by facilitating women's employment rates and average incomes, and subsequently by influencing who is employed and the distribution of women's incomes. Regarding the latter mechanism of family policy, little is known about how this affects vertical income inequality - as will be discussed in detail in the next sections. Regarding the former, however, there is by now a fairly clear consensus that without the rise in women's employment and earnings inequality between households would have been higher. This literature, however, only covered inequality among couples, and only shows the average effect of women's rising employment on vertical income inequality.

Early studies hypothesized that with more women entering the labor market, vertical income inequality between households was bound to rise when spouses' earnings were positively correlated, and to decline with spouses' earnings were negatively correlated (Mincer, 1962). There is indeed a tendency for higher educated women and women with higher earnings to be married to (/live together with) spouses who themselves have high levels of education and earnings, which is referred to as homogamy or endogamy (Kalmijn, 1998; Schwartz, 2013). Indeed, educational homogamy is found to boost the correlation between spouses' earnings (Breen \& Salazar, 2011), and this homogamy of earnings in itself is a factor that contributes to more vertical inequality among households (Nieuwenhuis, Van der Kolk, \& Need, 2017b). However, when inequality is measured in relative terms - as it typically is - a positive correlation between the earnings of spouses is a required but not a sufficient condition for women's earnings to increase inequality between households (Lam, 1997). Even when spouses' earnings are positively correlated, inequality between households will only be exacerbated by 
women's earnings when the inequality among women is sufficiently high compared to inequality among men's earnings. This is an important point, as it shows that to understand how women's earnings affect inequality between households not only depends on the degree to which spouses' earnings are correlated, but also on the level of inequality among women themselves. As more women entered the labor market, their (potential) earnings were argued to become more important when it comes to partner selection, thus promoting homogamy (Oppenheimer, 1988, 1994; Sweeney \& Cancian, 2004). Yet, at the same time, more women having an income of their own reduced inequality among women because of the simple fact that fewer women had zero earnings (Cancian \& Reed, 1998; Gregory, 2011). Thus, the rise in women's earnings observed in recent decades set into motion two dynamics with opposite outcomes (Nieuwenhuis et al., 2017b). On the one hand, women's earnings tend to be higher in households where their partner also has high earnings, thus increasing vertical inequality. On the other, more women have earnings. This reduces income differences among women, which in turn reduces vertical inequality. The latter dynamic has been more powerful in recent decades, explaining how the rise of women's earnings has reduced vertical inequality.

With only a few exceptions (Esping-Andersen, 2007, 2009), the inequality-reducing impact of women's employment and earnings was successfully replicated in contexts as widely different as Sweden (Björklund, 1992), Norway (Mastekaasa \& Birkelund, 2011), the United Kingdom (Harkness, Machin, \& Meguir, 1996; Machin \& Waldfogel, 1996), the United States (Betson \& Van der Gaag, 1984; Cancian \& Reed, 1998; Treas, 1987), Ireland (Callan, Nolan, O'Neill, \& Sweetman, 1998), Mexico (Campos-Vázquez, Hincapié, \& Rojas-Valdés, 2012), and Brazil (Sotomayor, 2009). In many of these countries, women's earnings reduced inequality even though they were positively correlated to those of their spouses.

The degree to which women's earnings reduce vertical income inequality between households varies substantially across countries, as was highlighted in a number of country-comparative studies. Cancian and Schoeni (1998) compared 10 developed countries to show that women's earnings reduced vertical inequality in all countries, and that this attenuating impact became stronger over time despite the employment rising faster among women married to high-income spouses than among women married to spouses with middle-class incomes. They further calculated that the correlation between spouses' earnings would have to increase substantially in order to nullify this attenuating impact of women's earnings on vertical inequality. Examining 14 European countries with widely different employment rates among women, 
Pasqua (2008) also finds that in all countries women's earnings reduce inequality between households. In countries where women's participation in the labor market was lower, inequality among women was higher while in these countries there was more potential to reduce inequality between households further by promoting more universal women's employment rates. In line with these findings, Harkness (2013) also finds that women's earnings reduced inequality more strongly in the Nordic countries with high rates of women's employment, compared to for instance southern European countries. Moreover, she further contributed the insight that closing the gender pay gap would further reduce inequality among households, although this impact would be smaller than what could be achieved by further raising women's employment rates. Would more women work full-time jobs across OECD countries, this would further reduce inequality between households (OECD, 2015). Nieuwenhuis, Van Lancker, Collado, and Cantillon (2020) also found the rise of women's employment to be associated with a reduction in relative poverty rates.

To illustrate cross-country variation in the degree to which trends in women's employment and earnings have reduced inequality between households, Fig. 25.2 summarizes results published elsewhere (Nieuwenhuis et al., 2017b; Nieuwenhuis, Need, \& Van der Kolk, 2019). Among heterosexual

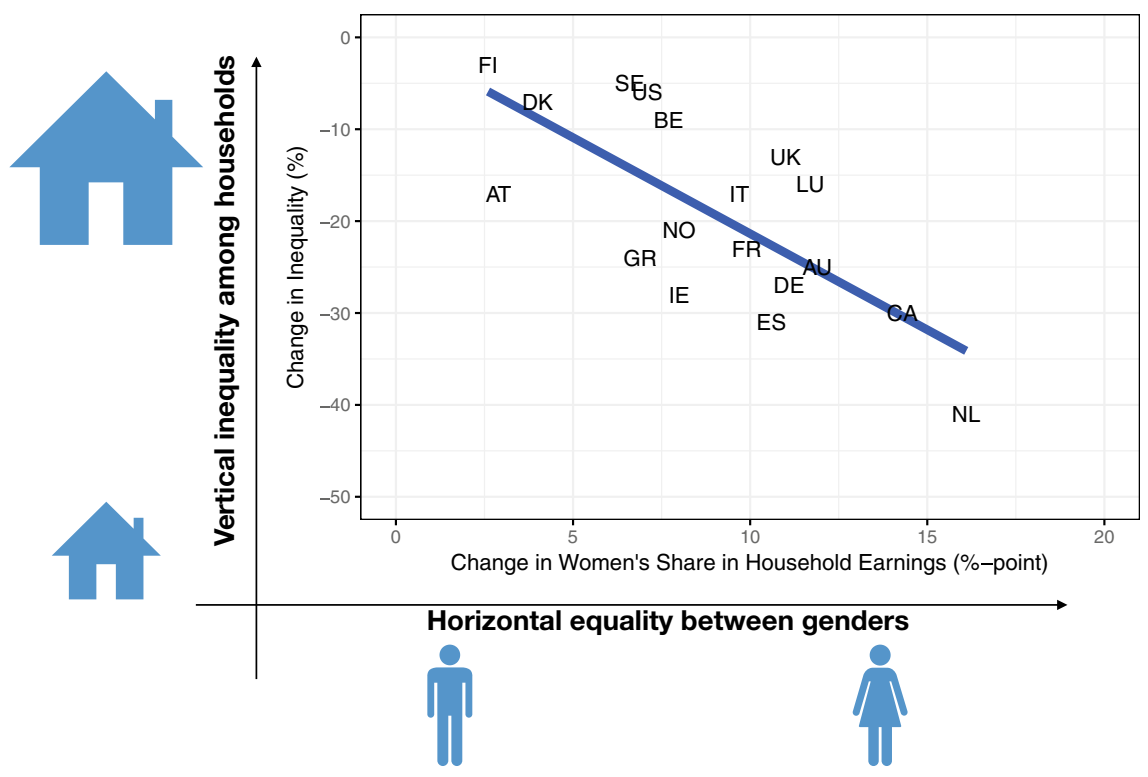

Fig. 25.2 Rise in women's earnings (1981-2008) associated with lower inequality among households of couples 
couples across 18 OECD countries, the share of total household earnings contributed by women was measured around 1980 and 2010. In all countries-at both points in time-women's earnings constitute less than half of average household earnings, but their share increased over time. It was then determined how much the change in women's earnings in total household earnings ( $x$-axis) had contributed to vertical inequality between households ( $y$-axis). In other words, how much higher/lower observed levels of inequality are around 2010 compared to a simulated scenario in which women's earnings had remained the same since the 1980s. These analyses were based on the strong assumption that nothing else changed in this period, but are still informative about the potential magnitude of how much changes in women's earnings affected inequality between households. Figure 25.2 shows how the increased share of women's earnings in total household earnings was associated with a reduction of vertical inequality in each of the countries, and how this impact was strongest in countries that had relatively low rates of women's employment (and consequently earnings) in the 1980s, such as the Netherlands. This is a figure that shows the impact of trends in women's share in total household earnings, which explains why the Nordic countries—already showing high rates of women's employment and earnings in the 1980s — show such a small reduction in vertical inequality.

An early analysis of the impact of family policies, based on the data summarized in Fig. 25.2 (Nieuwenhuis et al., 2019), showed that workfamily reconciliation policies as paid parental leave and public childcare were indeed associated with women's earnings more strongly reducing vertical inequality. Although these policies were found associated with a somewhat elevated correlation between spouses' earnings (increasing inequality), this effect was outweighed by the attenuating impact of a reduction in the inequality among women themselves. The study also examined the impact of policies typically associated with the traditional breadwinner model, such as family allowances and tax benefits for families with children, but found these not to be associated with vertical inequality between households.

\section{Family Policies as Determinant of Vertical Economic Inequality: A Research Agenda}

The literature summarized in the previous section demonstrates that women's earnings have attenuated inequality between households, and suggests that family policies can indeed facilitate this, but leaves unanswered important questions pertaining to the mechanisms through which family policies affect 
inequality. A research agenda on understanding how family policies might affect vertical inequality between households addresses a number of questions. Who uses family policies, what are the benefits of this use in terms of their earnings/incomes, and with whom do they form a household? These questions are interrelated, and the vast literature on family policy outcomes addresses each of these questions, as has been demonstrated throughout this Handbook. The research agenda proposed here builds on what has already been learned. Below, I revisit some of the ongoing debates in the family policy literature and relate these debates to new questions from the perspective of vertical inequality between households.

\section{Who Uses?}

It has long been acknowledged that the benefits of family policies (just like many other types of policy) are not the same for everyone. For example, higher educated parents are substantially more likely to enroll their children in public childcare compared to lower educated parents (Van Lancker, 2018a; Van Lancker \& Ghysels, 2012). Cash-for-care schemes (and other forms of very long, low-paid leave) may be considered a mechanism of exclusion from the labor market. Indeed, the Norwegian cash-for-care system was found more likely to be used by mothers with lower levels of education, lower income, and with a migration background (Bugum \& Kvande, 2013). In contrast, child benefits are also not uniformly distributed but sometimes have policy designs that benefit higher income families (Van Lancker \& Van Mechelen, 2015). Fathers are more likely to take parental leave when they are highly educated, but less likely when they are self-employed, work on temporary contracts, or in the private sector (Geisler \& Kreyenfeld, 2011; Romero-Balsas, 2012).

For the research agenda developed here, the use of family policies is to be differentiated by people in different positions on the income distribution (e.g., by income decile). This will shed light on the question whether different family policies have the potential to lift up the bottom of the income distribution, strengthen or hollow out the middle, or ensure that the top of the income distribution gets ahead even further. The question of who uses family policies of course also relates to fathers, to which I will return in the section on "with whom." 


\section{What Income Effect?}

It is not only important to understand where in the income distribution people are who use family policies, but also what the effect of that use is in terms of earnings and income. The additional income earned in relation to the use of family policy may also vary across the income distribution. In other words, it matters where in the income distribution people end up after using the family policy, or alternatively where they would have been had it not been for using family policies. Two debates come to the fore here.

The first ongoing debate pertains to potential trade-offs in family policy outcomes (Pettit \& Hook, 2009), not only with respect to gender but also class (see Chapter 11 by Hook and $\mathrm{Li}$ in this volume). In countries where a large proportion of women are integrated into the labor market, women were less likely to be in high-status and (importantly here) well-paid positions (Semyonov, 1980). Welfare state interventions that include paid maternity leave and public childcare (as well as a large public sector) were found to facilitate women's employment, but also found to promote occupational segregation with women overrepresented in "female-typed" occupations and underrepresented in managerial positions (Mandel \& Semyonov, 2006), which in turn was associated with wage penalties (Mandel, 2013). Taking a different position in this debate, Korpi, Ferrarini, and Englund (2013) argue that these studies only find a lower likelihood for women to reach top positions because they do not account for the large numbers of women remaining outside of the labor market in countries without work-family reconciliation family policies. Instead, they argue that these policies only affect the likelihood that women reach a top position relative to all working women (with the relative proportion of women in top positions relative to all working women being lower in countries with policies that also integrate a large number of lower skilled into employment) but do not affect the likelihood that any woman reaches a top position (also see: Grönlund \& Magnusson, 2016).

Secondly, the question remains open how family policies affect wage gaps across the income distribution (including, but not necessarily limited to, gender and motherhood wage gaps). Although there is plenty of literature on (determinants of) wage gaps (Blau, 2016; Blau \& Kahn, 2017), such analyses often focus on socioeconomic characteristics such as level of education, rather than income position. For instance, Halldén et al. (2016) found that although public childcare helped reduce the motherhood pay gap, this effect did not seem to differ among higher and lower educated mothers. On the other hand, Budig and Hodges (2010) examined motherhood wage penalty 
across the wage distribution, finding it to be bigger for low-wage mothers (for a methodological comment, see Killewald \& Bearak, 2014). Examining the impact of time spent on housework on wages, Cooke and Hook (2018) find that men do the least housework and incur the largest wage penalty for doing so when they are at the top of men's wage distribution, whereas for women incur a larger wage penalty at the bottom of their wage distribution. Morosow and Cooke (2018) found that Finnish fathers who take parental leave incur a wage penalty, but only those fathers at the bottom of the wage distribution.

Taking together who uses family policies and to what income effect raises the question to what extent people at different positions in the income distribution use various family policies, and how the income or wage effects associated with using these policies differ across the income distribution. A family policy that is beneficial to wages may reduce vertical levels of income inequality when it is predominantly used by people at the lower end of the income distribution and/or when its effects are strongest at the bottom. Yet, if a policy is mostly used by people at relatively high-income positions and/or the effects are strongest at the top, such policy may exacerbate vertical income inequality.

\section{With Whom?}

Perhaps the cornerstone of the research agenda developed here is to examine the family policy outcomes in relation to household composition and processes of household formation. Whether family policies will affect income inequality between households not only depends on who the individuals are that use family policies and to what income effect, but also on the incomes of others with whom people form a household. If those with a higher (a priori) income are more likely to use a specific family policy and/or to benefit from this use to a greater extent, this will exacerbate inequality to a larger extent if these individuals live with (for instance) a high-earning partner. In other words, this research agenda brings to the fore a dyadic perspective on family policy outcomes. Such a dyadic perspective brings into focus at least three avenues for further developing research in family policy outcomes-in general as well as with a specific focus on vertical income inequality. The first is how the use and associated income effects of family policy relate to other household members (if any). The second is how family policies may affect household composition. The third pertains to the within-household sharing of - and control over-resources.

It is well-documented that the uses and benefits of family policies vary across individuals, and often along the socioeconomic spectrum (see sections 
"Who Uses?" and "What Income Effect?"). However, to understand how family policies can affect vertical inequality between households, it should also be understood how use and benefits thereof depend on socioeconomic characteristics of other household members. So far, only a small literature on this seems to be emerging.

In recent years, fathers are increasingly given-and have become more likely to make use of-parental leave rights, which is in part related to how the leave policy is implemented (Eydal et al., 2015; Karu \& Tremblay, 2017; see Chapter 15 by Bartova and Keizer). Within couples, mothers took longer leave when their (male) partner held traditional attitudes, whereas how long leave he took was not affected by her views. Fathers did take more leave if their partner had a high level of education (Stertz, Grether, \& Wiese, 2017). Also in Germany, fathers were most likely to take leave when their partner had a higher level of education than themselves (Geisler \& Kreyenfeld, 2011). Moreover, fathers were more likely to take leave when their (female) partner worked full-time and had a high income (Reich, 2011). As such, this dyadic perspective not only brings into focus the question how partners influence each others' use of parental leave and other family policies, but also how their partners' use of family policies affect their own incomes.

The question of how family policy outcomes vary by with whom people live, also needs to include people living without a partner, with single parents being a case in point in this context. The rise of single parenthood has been associated with a rise in household inequality (Zagel \& Breen, 2019), but it seems likely that this impact depends on the institutional context (of which family policies may be an important part) that shapes how well single parents are doing financially. When it comes to single mothers, it was found that they use parental leave and childcare to similar extents as mothers living with a partner, but that the use of parental level and childcare was associated with future employment more strongly among single mothers (Van Lancker, 2018b). In Sweden, single fathers were found to continue using parental leave after they had separated from the mother of their child(ren) (Duvander $\&$ Korsell, 2018). Both parental leave and child benefits were found to reduce income poverty to a larger extent among single parents compared to among couples, which in the case of parental leave was mediated by single parents' higher levels of employment (Maldonado \& Nieuwenhuis, 2015).

The second way in which family policy outcomes are linked to with whom people live, is through how processes of family formation are related to family policy contexts. The most developed literature in this regard deals with the link between family policies and fertility. The relevance of this literature for vertical inequality lies, of course, in the profound consequences of having 
children for employment, division of labor within households, and the way equivalent income per household member is calculated. Both work-family reconciliation policies (paid leave, childcare) and financial support policies to families with children (child benefits) were found associated with higher fertility in a panel study covering 18 OECD countries from 1982 to 2007 (Luci-Greulich \& Thévenon, 2013; similar conclusion in: Chapter 9 by Adema, Clarke, and Thévenon; Diprete, Mogan, Engelhardt, and Pacalova, 2003; Rovny, 2011). However, such associations were generally small and not differentiated by for instance education and income, which would be required for the study of vertical inequality.

Little is known about the degree to which family policies affect homogamy - the degree to which highly educated and/or high-income partners form couples_or hypogamy in which women have higher levels of education than their male partner (Van Bavel, Schwartz, \& Esteve, 2018). It has, however, been shown how with rising female labor force participation rates (due to family policy or otherwise), as well as with women's rising levels of education, women's economic position and prospects became more important on the marriage market and resulted in higher degrees of homogamy (Oppenheimer, 1994). Mediated by female labor force participation rates and women's share in household earning, paid leave, and childcare were indeed found to be associated with a higher correlation between spouses' earnings (Nieuwenhuis et al., 2019).

Family policies can further relate to patterns of relationship formation and dissolution. For instance, family policies characterized by a high degree of familization were found to be associated with lower complexity of family formation trajectories - thus with fewer separations-whereas individualization (e.g., childcare policies) was associated with a higher degree of complexity (Van Winkle, 2019).

Third, the focus on with whom people live brings attention to the issue that it does not only matter how much income the household receives, but also who in the household receives the income. Many measures of inequality (as well as poverty) assume that all household income is shared equally. However, it has often been documented that this is not the case, and that women often have less control over household resources than men (Bennett, 2013). As a consequence, income levels (or inequality thereof) may hide that women experience lower living standards than their partners (Cantillon, 2013). On the one hand, this may mean that mainstream inequality indicators based on household income underestimate real development in the inequality of income or living standards between individuals. On the other hand-and more relevant to the focus of the research agenda 
developed here-it was shown that in countries where more women have an income of their own, household poverty (as a form of inequality) was lower (Nieuwenhuis, Munzi, Neugschwender, Omar, \& Palmisano, 2019).

Although it was shown that in countries with more extensive workfamily reconciliation policies (e.g., paid leave and ECEC) a larger share of total household earnings is earned by women (Nieuwenhuis et al., 2019; Stier \& Mandel, 2009), and although it seems plausible that the employment facilitated by these policies promotes economic independence, this does not explicitly examine the inequality of control over household earnings. How family policies relate to women's economic independence within households across the income distribution, and how that relates to household-level income inequality, remains open for future investigation.

\section{Conclusion}

Women's earnings have a strong tendency to reduce relative income inequality among the households of couples, and through this mechanism workfamily reconciliation policies are also related to lower inequality. This means that family policies should not only be considered in analyses of horizontal inequality between women and men (or mothers and women without children), but also as determinants of vertical income inequality between households. The literature on high and rising levels of vertical inequality so far has not been particularly sensitive to issues of gender (in)equality, and it may become so by expanding its focus to issues of household formation and earnings across the income distribution.

This chapter developed a research agenda for examining family policy outcomes with respect to vertical economic inequality, arguing that family policies wrongly have been neglected as a determinant of vertical economic inequality. Three questions are central to this research agenda: who uses family policy, to what income effect, and with whom do people live? These questions are not new, although some have received more attention than others, but when examined in conjunction with, and with attention to, variation across the income distribution, important insights will be gained in the mechanisms through which family policies can be a determinant of vertical economic inequality.

Several other issues in the family policy literature are relevant to this research agenda, but were not integrated as these issues apply more generally. To separate design or implementation of family policy from its use and the income effects of that use, it is important to have family policy indicators 
that measure the social rights provided by these policies - in line with the discussion on indicators developed in Chapter 24 by Sirén, Doctrinal, Van Lancker, and Nieuwenhuis. Details of implementation might matter substantially for inequality, for instance, with respect to who in the family receives the child benefits (e.g., the household as a whole, or both parents individually receiving half), or the degree of low-income targeting (Marchall \& Van Lancker, 2019). In addition, even though most of the research cited here pertained to national-level family policies, it should come as no surprise in this Handbook that other levels of family policy implementation may matter. Even though it was demonstrated in Chapters 3 by Jenson, 4 by White, and 5 by Razavi that supranational and international organizations do not implement family policies themselves, they do have an interest in reducing economic inequality. Subnational variation in family policy availability may in fact give rise to economic differences between regions. To the extent that rural areas provide more policies to support dual-earner families, this may exacerbate rural-urban income differences. To the extent that the "final availability" (see Chapter 21 by Chung) of family policies in organizations is greater for high-skilled employees and/or those in managerial positions (see Chapter 22 by Begall and Van der Lippe), this also may exacerbate inequality between workers and consequently between households.

Developing an understanding of the mechanisms underlying family policy as a determinant of vertical economic inequality will not only further the literature on family policy outcomes, but also contribute to tackle one of the key challenges of our time: high and rising levels of inequality. As such, family policy might be incorporated in broader analyses of economic inequality. The focus on family policies may also shed light on two more specific challenges of inequality. The first relates to stalled trends in improving gender equality in the labor market (England, 2010), as for instance seen at comparatively high levels of equality in the Nordic countries but also in the United States. In these countries, the question is how future inequality will evolve as it is no longer attenuated by the rise in women's employment and earnings. Here, an understanding of the mechanisms through which family policies affect economic inequality is pertinent, as it may help propose policies that not only raise the number of employed women, but do so in a way that equalizes opportunities and earnings across households. The second relates to the challenges of family diversity in the dual-earner model. On the one hand, family policies such as paid leave and public childcare have facilitated the rise of dual-earner families. This has benefitted gender equality, the income stability of these families, and reduced income inequality among couples, but it may also have raised the living standards in a country (or for instance urban areas). 
While, for instance, single parents undoubtedly and greatly benefit from such work-family reconciliation policies, the presence of a large number of dualearner families may also make it more difficult for singles and single parents alike to achieve what are considered acceptable living standards (Alm, Nelson, $\&$ Nieuwenhuis, 2020).

Family policies have empirically been linked to women's employment and earnings, and consequently to lower vertical income inequality. Yet, the literature also makes abundantly clear that family policies come with trade-offs along the lines of gender and class, as well as Matthew effects. These mechanisms need to be better understood to integrate family policy in analyses of - and recommendation against-high and rising inequality. The challenge ahead is to understand what (combination of) family policies may be inclusive to a wide range of families across the full width of the income distribution.

Acknowledgements This research was financially supported by FORTE: the Swedish Research Council for Health, Working Life, and Welfare (grant number 2018-00988).

\section{References}

Alm, S., Nelson, K., \& Nieuwenhuis, R. (2020). The diminishing power of one? Welfare state retrenchment and rising poverty of single-adult households in Sweden 1988-2011. European Sociological Review, 36 (2), 198-217.

Atkinson, A. B. (2015). Inequality: What can be done? Cambridge, MA: Harvard University Press.

Autor, D. H. (2014). Skills, education, and the rise of earnings inequality among the "other 99 percent". Science. https://doi.org/10.1126/science.1251936.

Beckfield, J. (2019). Unequal Europe: Regional integration and the rise of European inequality. Oxford: Oxford University Press.

Bennett, F. (2013). Researching within-household distribution: Overview, developments, debates, and methodological challenges. Journal of Marriage and Family, 75(3), 582-597. https://doi.org/10.1111/jomf.12020.

Bernstein, J. (2016). Wages in the United States: Trends, explanations, and solutions. In I. Kirsch \& H. Braun (Eds.), The dynamics of opportunity in America (pp. 167-195). Cham: Springer International Publishing. http://doi.org/10. 1007/978-3-319-25991-8_6.

Betson, D., \& Van der Gaag, J. (1984). Working married women and the distribution of income. The Journal of Human Resources, 19(4), 532. https://doi.org/10. 2307/145946. 
Björklund, A. (1992). Rising female labour force participation and the distribution of family income - the Swedish experience. Acta Sociologica, 35(4), 299-309. https://doi.org/10.1177/000169939203500403.

Blau, F. D. (2016). Gender, inequality, and wages. In A. C. Gielen \& K. F. Zimmermann (Eds.). Oxford: Oxford University Press.

Blau, F. D., \& Kahn, L. M. (2017). The gender wage gap: Extent, trends, and explanations. Journal of Economic Literature, 55(3), 789-865. https://doi.org/10. 1257/jel.20160995.

Breen, R., \& Salazar, L. (2011). Educational assortative mating and earnings inequality in the United States 1. American Journal of Sociology, 117(3), 808-843. https://doi.org/10.1086/661778.

Brussevich, M., Dabla-Norris, E., Kamunge, C., Karnane, P., Khalid, S., \& Kochhar, K. (2018). Gender, technology, and the future of work (No. SND/18/07). IMF staff discussion notes (pp. 1-36).

Budig, M. J., \& Hodges, M. J. (2010). Differences in disadvantage. American Sociological Review, 75(5), 705-728. https://doi.org/10.1177/000312241 0381593.

Bungum, B., \& Kvande, E. (2013). The rise and fall of cash for care in Norway: Changes in the use of child-care policies. Nordic Journal of Social Research, 4, 24.

Bussemakers, C., van Oosterhout, K., Kraaykamp, G., \& Spierings, N. (2017). Women's worldwide education-employment connection: A multilevel analysis of the moderating impact of economic, political, and cultural contexts. World Development, 99, 28-41. https://doi.org/10.1016/j.worlddev.2017.07.002.

Callan, T., Nolan, B., O’Neill, D., \& Sweetman, O. (1998). Female labour supply and income inequality in Ireland. Economics, finance and accounting department Working Paper Series.

Campos-Vázquez, R. M., Hincapié, A., \& Rojas-Valdés, R. I. (2012). Family income inequality and the role of married females' earnings in Mexico: 19882010. Latin American Journal of Economics, 49(1), 67-98. https://doi.org/10. 4067/S0719-04332012000100003.

Cancian, M., \& Reed, D. (1998). Assessing the effects of wives' earnings on family income inequality. Review of Economics and Statistics, 80(1), 73-79. https://doi. org/10.1162/003465398557348.

Cancian, M., \& Schoeni, R. F. (1998). Wives' earnings and the level and distribution of married couples" earnings in developed countries. Journal of Income Distribution, 8(1), 45-61. https://doi.org/10.1016/S0926-6437(99)80003-1.

Cantillon, S. (2013). Measuring differences in living standards within households: Differences in living standards within households. Journal of Marriage and Family, 75(3), 598-610. https://doi.org/10.1111/jomf.12023.

Charles, M. (2011). A world of difference: International trends in women's economic status. Annual Review of Sociology, 37(1), 355-371. https://doi.org/ 10.1146/annurev.soc.012809.102548.

Charles, M., \& Grusky, D. B. (2004). Occupational ghettos: The worldwide segregation of women and men. Stanford, CA: Stanford University Press. 
Cooke, L. P., \& Hook, J. L. (2018). Productivity or gender? The impact of domestic tasks across the wage distribution. Journal of Marriage and Family, 80(3), 721736. https://doi.org/10.1111/jomf.12467.

Cowell, F. (2011). Measuring inequality. Oxford: Oxford University Press.

Diprete, T. A., Morgan, S. P., Engelhardt, H., \& Pacalova, H. (2003). Do crossnational differences in the costs of children generate cross-national differences in fertility rates? Population Research and Policy Review, 22(5/6), 439-477. https:// doi.org/10.1023/B:POPU.0000020961.89068.91.

Duvander, A.-Z., \& Korsell, N. (2018). Whose days are left? Separated parents' use of parental leave in Sweden. In R. Nieuwenhuis \& L. C. Maldonado (Eds.), The triple bind of single-parent families: Resources, employment and policies to improve wellbeing (1st ed., pp. 236-283). https://doi.org/10.2307/j.ctt2204rvq.

Ebbinghaus, B. (2011). The varieties of pension governance. Oxford University Press. https://doi.org/10.1093/acprof:oso/9780199586028.001.0001.

Ebbinghaus, B., \& Visser, J. (2000). Trade unions in Western Europe Since 1945. Oxford: Macmillan Reference.

England, P. (2010). The gender revolution: Uneven and stalled. Gender \& Society, 24(2), 149-166. https://doi.org/10.1177/0891243210361475.

Esping-Andersen, G. (2007). Sociological explanations of changing income distributions. American Behavioral Scientist, 50(5), 639-658. https://doi.org/10.1177/ 0002764206295011.

Esping-Andersen, G. (2009). Incomplete revolution: Adapting welfare states to women's new roles. Cambridge: Polity.

European Union (EU), \& European Institute for Gender Equality (EIGE). (2020). Beijing + 25: The fifth review of the implementation of the Beijing platform for action in the EU member states. https://op.europa.eu/publication/manifestation_i dentifier/PUB_MH0119036ENN.

Evertsson, M. (2014). Gender ideology and the sharing of housework and child care in Sweden. Journal of Family Issues, 35(7), 927-949. https://doi.org/10.1177/019 $2513 X 14522239$.

Eydal, G. B., Gíslason, I. V., Rostgaard, T., Brandth, B., Duvander, A.-Z., \& Lammi-Taskula, J. (2015). Trends in parental leave in the Nordic countries: Has the forward march of gender equality halted? Community, Work \& Family, 18(2), 167-181. https://doi.org/10.1080/13668803.2014.1002754.

Frey, C. B. (2019). The technology trap. Princeton: Princeton University Press.

Gambaro, L., Stewart, K., \& Waldfogel, J. (2015). An equal start? Providing quality early education and care for disadvantaged children. Bristol: Policy Press.

Geisler, E., \& Kreyenfeld, M. (2011). Against all odds: Fathers' use of parental leave in Germany. Journal of European Social Policy, 21(1), 88-99. https://doi.org/10. $1177 / 0958928710385732$.

Goldin, C. (2014). A grand gender convergence: Its last chapter. American Economic Review, 104(4), 1091-1119. https://doi.org/10.1257/aer.104.4.1091.

Gornick, J. C., \& Meyers, M. K. (2003). Families that work: Policies for reconciling parenthood and employment. New York: Russell Sage Foundation. 
Gregory, M. (2011). Gender and economic inequality. In T. Smeeding, W. Salverda, \& B. Nolan (Eds.), The oxford handbook of economic inequality. Oxford: Oxford University Press. http://doi.org/10.1093/oxfordhb/9780199606061.013.0012.

Grönlund, A., \& Magnusson, C. (2016). Family-friendly policies and women's wages-Is there a trade-off? Skill investments, occupational segregation and the gender pay gap in Germany, Sweden and the UK. European Societies, 18(1), 91-113. http://doi.org/10.1080/14616696.2015.1124904.

Halldén, K., Levanon, A., \& Kricheli-Katz, T. (2016). Does the motherhood wage penalty differ by individual skill and country family policy? A longitudinal study of ten European countries. Social Politics: International Studies in Gender, State \& Society, 23(3), 363-388. https://doi.org/10.1093/sp/jxv032.

Harkness, S. (2013). Women's employment and household income inequality. In J. C. Gornick \& M. Jäntti (Eds.), Income inequality: Economic disparities and the middle class in affluent countries (pp. 207-233). Stanford, CA: Stanford University Press.

Harkness, S., Machin, S., \& Meguir, C. (1996). Women's pay and household incomes in Britain, 1979-1991. In New inequalities: The changing distribution of income and wealth in the United Kingdom. Cambridge: Cambridge University Press.

Iversen, T., \& Soskice, D. (2019). Democracy and prosperity. Princeton, NJ: Princeton University Press.

Kalleberg, A. L. (2009). Precarious work, insecure workers: Employment relations in transition. American Sociological Review, 74(1), 1-22. https://doi.org/10.1177/ 000312240907400101.

Kalmijn, M. (1998). Intermarriage and homogamy: Causes, patterns, trends. Annual Review of Sociology, 24(1), 395-421. http://doi.org/10.1146/annurev.soc.24. 1.395.

Karu, M., \& Tremblay, D.-G. (2017). Fathers on parental leave: An analysis of rights and take-up in 29 countries. Community, Work \& Family, 21(3), 344-362. http://doi.org/10.1080/13668803.2017.1346586.

Killewald, A., \& Bearak, J. (2014). Is the motherhood penalty larger for low-wage women? A comment on quantile regression. American Sociological Review, 79(2), 350-357. https://doi.org/10.1177/0003122414524574.

Knight, C. R., \& Brinton, M. C. (2017). One egalitarianism or several? Two decades of gender-role attitude change in Europe. American Journal of Sociology, 122(5), 1485-1532. https://doi.org/10.1086/689814.

Korpi, W. (1983). The democratic class struggle. Boston: Routledge.

Korpi, W. (2000). Faces of inequality: Gender, class, and patterns of inequalities in different types of welfare states. Social Politics: International Studies in Gender, State \& Society, 7(2), 127-191. https://doi.org/10.1093/sp/7.2.127.

Korpi, W., Ferrarini, T., \& Englund, S. (2013). Women's opportunities under different family policy constellations: Gender, class, and inequality tradeoffs in Western countries re-examined. Social Politics: International Studies in Gender, State \& Society, 20(1), 1-40. https://doi.org/10.1093/sp/jxs028. 
Lam, D. (1997). Demographic variables and income inequality. In M. R. Rosenzweig \& O. Stark (Eds.), Handbook of population and family economics (pp. 10151059). Dordrecht: Elsevier.

Lesthaeghe, R. (2010). The unfolding story of the second demographic transition. Population and Development Review, 36 (2), 211-251.

Lewis, J. (1992). Gender and the development of welfare regimes. Journal of European Social Policy, 2(3), 159-173. https://doi.org/10.1177/095892879200 200301.

Lohmann, H., \& Marx, I. (2018). Handbook of research on in-work poverty. Cheltenham: Edward Elgar.

Luci-Greulich, A., \& Thévenon, O. (2013). The Impact of Family Policies on Fertility Trends in Developed Countries: L'influence des politiques familiales sur les tendances de la fécondité des pays développés. European Journal of Population / Revue Européenne de Démographie, 29(4), 387-416. https://doi.org/10.1007/s10 680-013-9295-4.

Machin, S., \& Waldfogel, J. (1996). The decline of the male breadwinner: Changing shares of husbands' and wives' earnings in family income. London: LSE Research Online. Retrieved from http://sticerd.lse.ac.uk/case/_new/publications/series.asp? prog $=$ WSP.

Maldonado, L. C., \& Nieuwenhuis, R. (2015). Family policies and single parent poverty in 18 OECD countries, 1978-2008. Community, Work \& Family, 18(4), 395-415. https://doi.org/10.1080/13668803.2015.1080661.

Mandel, H. (2013). Up the down staircase: Women's upward mobility and the wage penalty for occupational feminization, 1970-2007. Social Forces, 91(4), 11831207. https://doi.org/10.1093/sf/sot018.

Mandel, H., \& Semyonov, M. (2006). A welfare state paradox: State interventions and women's employment opportunities in 22 countries. American Journal of Sociology, 111(6), 1910-1949. https://doi.org/10.1086/499912.

Marchal, S., \& Van Lancker, W. (2019). The measurement of targeting design in complex welfare states: A proposal and empirical applications. Social Indicators Research, 143(2), 693-726. https://doi.org/10.1007/s11205-018-1995-z.

Marx, I., \& Nelson, K. (2013). Minimum income protection in flux. Basingstoke: Palgrave Macmillan.

Mastekaasa, A., \& Birkelund, G. E. (2011). The equalizing effect of wives' earnings on inequalities in earnings among households. European Societies, 13(2), 219237. https://doi.org/10.1080/14616696.2010.514350.

Milanovic, B. (2016). Global inequality: A new approach for the age of globalization. Cambridge: Harvard University Press.

Mincer, J. (1962). Labor force participation of married women: A study of labor supply. Aspects of Labor Economics.

Möhring, K. (2015). Employment histories and pension incomes in Europe: A multilevel analysis of the role of institutional factors. European Societies, 17(1), 3-26. https://doi.org/10.1080/14616696.2014.934874. 
Möhring, K. (2016). Life course regimes in Europe: Individual employment histories in comparative and historical perspective. Journal of European Social Policy, 26(2), 124-139. https://doi.org/10.1177/0958928716633046.

Morosow, K., \& Cooke, L. P. (2018). Why daddy doesn't do it: Paternal leave effects of the wage distribution (Spade Working Paper 2018:06). http://www.diva-portal. org/smash/record.jsf?pid=diva2\%3A1340904\&dswid=-9269.

Moss, P., Duvander, A.-Z., \& Koslowski, A. (2019). Parental leave and beyond. Bristol: Policy Press.

Nelson, K. (2013). Social assistance and EU poverty thresholds 1990-2008. are European welfare systems providing just and fair protection against low income? European Sociological Review, 29(2), 386-401. http://doi.org/10.1093/ esr/jcr080.

Nieuwenhuis, R., Munzi, T., Neugschwender, J., Omar, H., \& Palmisano, F. (2019). Gender equality and poverty are intrinsically linked: A contribution to the continued monitoring of selected sustainable development goals. UN. https://doi.org/ 10.18356/bd01abcb-en.

Nieuwenhuis, R., Need, A., \& Van Der Kolk, H. (2012). Institutional and demographic explanations of women's employment in 18 OECD Countries, 1975-1999. Journal of Marriage and the Family, 74(3), 614-630. https://doi. org/10.1111/j.1741-3737.2012.00965.x.

Nieuwenhuis, R., Need, A., \& Van Der Kolk, H. (2017a). Is there such a thing as too long childcare leave? International Journal of Sociology and Social Policy, 37(1/2), 2-15. https://doi.org/10.1108/IJSSP-07-2015-0074.

Nieuwenhuis, R., Van der Kolk, H., \& Need, A. (2017b). Women's earnings and household inequality in OECD countries, 1973-2013. Acta Sociologica, 60(1), 3-20. https://doi.org/10.1177/0001699316654528.

Nieuwenhuis, R., Need, A., \& Van Der Kolk, H. (2019). Family policy as an institutional context of economic inequality. Acta Sociologica, 62(1), 64-80. http:// doi.org/10.1177/0001699318760125.

Nieuwenhuis, R., Van Lancker, W., Collado, D., \& Cantillon, B. (2020). Trends in women's employment and poverty rates in OECD countries: A KitagawaBlinder-Oaxaca decomposition. Italian Economic Journal, 6, 37-61.

OECD. (2015). In it together: Why less inequality benefits all. Paris: OECD Publishing.

Olivetti, C., \& Petrongolo, B. (2017). The economic consequences of family policies: Lessons from a century of legislation in high-income countries. Journal of Economic Perspectives, 31(1), 205-230. https://doi.org/10.1257/jep.31.1.205.

Oppenheimer, V. K. (1988). A theory of marriage timing. American Journal of Sociology, 94(3), 563-591. https://doi.org/10.1086/229030.

Oppenheimer, V. K. (1994). Women's rising employment and the future of the family in industrial societies. Population and Development Review, 20(2), 293. https://doi.org/10.2307/2137521.

Pasqua, S. (2008). Wives' work and income distribution in European countries, 5(2), 197-226. https://doi.org/10.1016/S0926-6437(99)80003-1. 
Pettit, B., \& Hook, J. L. (2009). Gendered tradeoffs: Women, family, and workplace inequality in twenty-one countries. New York: Russel Sage Foundation.

Piketty, T. (2014). Capital in the twenty-first century. Cambridge: The Belknap Press.

Reich, N. (2011). Predictors of fathers' use of parental leave in Germany. Population Review, 50(2). https://doi.org/10.1353/prv.2011.0011.

Romero-Balsas, P. (2012). Fathers taking paternity leave in Spain: Which characteristics foster and which hamper the use of paternity leave? Sociologia e Politiche Sociali, 106-131.

Rovny, A. E. (2011). Welfare state policy determinants of fertility level: A comparative analysis. Journal of European Social Policy, 21(4), 335-347. https://doi.org/ $10.1177 / 0958928711412221$.

Rubery, J. (2015). Austerity and the future for gender equality in Europe. ILR Review, 68(4), 715-741. https://doi.org/10.1177/0019793915588892.

Saez, E., \& Zucman, G. (2019). The Triumph of injustice: How the rich dodge taxes and how to make them pay. New York: W. W. Norton.

Schwartz, C. R. (2013). Trends and variation in assortative mating: Causes and consequences. Annual Review of Sociology, 39, 451-470. https://doi.org/10.1146/ annurev-soc-071312-145544.

Semyonov, M. (1980). The social context of women's labor force participation: A comparative analysis. American Journal of Sociology, 86 (3), 534-550. https://doi. org/10.1086/227280.

Sen, A. (1990). Gender and cooperative conflicts. In I. Tinker (Ed.), Persistent inequalities: Women and world development (pp. 123-149). Oxford: Oxford University Press.

Sotomayor, O. J. (2009). Changes in the distribution of household income in Brazil: The role of male and female earnings. World Development, 37(10), 1706-1715. https://doi.org/10.1016/j.worlddev.2009.03.003.

Stertz, A. M., Grether, T., \& Wiese, B. S. (2017). Gender-role attitudes and parental work decisions after childbirth: A longitudinal dyadic perspective with dualearner couples. Journal of Vocational Behavior, 101, 104-118. https://doi.org/10. 1016/j.jvb.2017.05.005.

Stier, H., \& Mandel, H. (2009). Inequality in the family: The institutional aspects of women's earning contribution. Social Science Research, 38(3), 594-608. https:// doi.org/10.1016/j.ssresearch.2009.01.008.

Sweeney, M. M., \& Cancian, M. (2004). The changing importance of white women's economic prospects for assortative mating. Journal of Marriage and Family, 66(4), 1015-1028. https://doi.org/10.1111/j.0022-2445.2004.00073.x.

Taylor-Gooby, P., Leruth, B., \& Chung, H. (2017). After austerity. Oxford: Oxford University Press.

Thévenon, O. (2011). Family policies in OECD countries: A comparative analysis. Population and Development Review, 37(1), 57-87. https://doi.org/10.1111/ j.1728-4457.2011.00390.x. 
Treas, J. (1987). The effect of women's labor force participation on the distribution of income in the United States. Annual Review of Sociology, 13, 259-288. https:// doi.org/10.1007/978-3-7908-2000-3.

Van Bavel, J., Schwartz, C. R., \& Esteve, A. (2018). The reversal of the gender gap in education and its consequences for family life. Annual Review of Sociology, 44(1), 341-360. https://doi.org/10.1146/annurev-soc-073117-041215.

Van der Lippe, T., \& Van Dijk, L. (2002). Comparative research on women's employment. Annual Review of Sociology, 28(1), 221-241. https://doi.org/10. 1146/annurev.soc.28.110601.140833.

Van Lancker, W. (2018a). Reducing inequality in childcare service use across European countries: What (if any) is the role of social spending? Social Policy \& Administration, 52(1), 271-292. https://doi.org/10.1111/spol.12311.

Van Lancker, W. (2018b). Does the use of reconciliation policies enable single mothers to work? A comparative examination of European countries. In R. Nieuwenhuis \& L. C. Maldonado (Eds.), The triple bind of single-parent families: Resources, employment and policies to improve well-being (pp. 239-261). Bristol: Policy Press.

Van Lancker, W., \& Ghysels, J. (2012). Who benefits? The social distribution of subsidized childcare in Sweden and Flanders. Acta Sociologica, 55(2), 125-142. https://doi.org/10.1177/0001699311433428.

Van Lancker, W., \& Van Mechelen, N. (2015). Universalism under siege? Exploring the association between targeting, child benefits and child poverty across 26 countries. Social Science Research, 50, 60-75. https://doi.org/10.1016/j.ssresearch. 2014.11.012.

Van Winkle, Z. (2019). Family polices and family life course complexity across 20th-century Europe. Journal of European Social Policy, 095892871988050. https://doi.org/10.1177/0958928719880508.

West, C., \& Zimmerman, D. H. (2009). Accounting for doing gender. Gender \& Society, 23(1), 112-122. https://doi.org/10.1177/0891243208326529.

Zagel, H., \& Breen, R. (2019). Family demography and income inequality in West Germany and the United States. Acta Sociologica, 62(2), 174-192. https://doi. org/10.1177/0001699318759404. 
Open Access This chapter is licensed under the terms of the Creative Commons Attribution 4.0 International License (http://creativecommons.org/licenses/by/4.0/), which permits use, sharing, adaptation, distribution and reproduction in any medium or format, as long as you give appropriate credit to the original author(s) and the source, provide a link to the Creative Commons licence and indicate if changes were made.

The images or other third party material in this chapter are included in the chapter's Creative Commons licence, unless indicated otherwise in a credit line to the material. If material is not included in the chapter's Creative Commons licence and your intended use is not permitted by statutory regulation or exceeds the permitted use, you will need to obtain permission directly from the copyright holder.

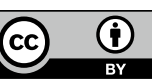

